of director of the Salters' Institute of Industrial Chemistry, where his experience both as a teacher and in industry undoubtedly proved of the greatest value. His keen interest in the City of London Companies was further shown by his election in 1919 as prime warden of the Worshipful Company of Dyers.

Although so actively engaged in experimental rosearch, Forster found the time to participate in the administration of the Chemical Society. After serving on the Couneil, he was honorary secretary during 1904-10, treasurer 1913-22 and vice-president 1910-13. The value of his contributions to science were recognized by the Society in 1918 by the award of its highest distinction, the Longstaff Medal. He was elected to the Royal Society in 1905 at the unusually early age of thirty-three, and he served on the Council. He was a regular attendant at the meetings of the British Association, being president of Section B at the Edinburgh meeting in 1920.

A complete change in Forster's life and one made at considerable personal sacrifice came in 1922 when, at the request of his friend Sir William Pope, he accepted the post of director of the Indian Institute of Science, Bangalore. The Institute, which we owe to the munificence of the Tata family, had passed through a somewhat difficult period, and it was clear that if it was to fulfil the hopes of its founders, a director of outstanding quality was required. This it found in Forster, and perhaps in the Institute will be found Forster's most lasting contribution to science. Not only did he win the loyalty and friendship of his staff, but he gained also the confidence and affection of the students. He and Lady Forster, whom he married in 1925, realized to the full their many difficulties. Their hospitality was boundless, and the Institute became a very happy family. His success as a director was due not only to his scientific attainments. He was a fine speaker, and he delighted in the social obligations which his position involved. No one will question that the high position which the Institute has now attained in India is due in large measure to the work which he did.

The many administrative duties of his post prevented Forster from continuing his scientific work in Bangalore, although for the first few years he did direct the work of some research students. But his interest in science never abated, and I personally owe much to his advice and encouragement. He was president of the Indian Science Congress in 1925 and he was an original fellow of the National Institute of Sciences. On his retirement in 1933, Forster settled in Mysore City, making occasional visits to Britain, the last being in 1939. After Lady Forster's death in 1941, his life was somewhat lonely, and he had every intention of returning permanently to London at the end of the War. He had hoped to enjoy once more the scientific life in which he had once played so prominent a part.

J. L. Stmonsen.

\section{Prof. John Borg}

THE death, on May 4, is reported of Prof. John Borg, the most renowned of Maltese botanists. He was formerly superintendent of agriculture, professor of natural history in the University, and director of the Botanic Garden in Malta. From these official posts he retired in 1933 ; but up to his death he maintained his interests in botany and agriculture, and he held the title of emeritus professor of natural history in the Royal University.
Borg's contributions to the advancement of biology were varied and included research in both the pure and applied fields. His influence on education was not limited to his academic activities but extended to public lectures and to articles in the local Press and other publications written in English or Maltese. In agriculture and horticulture, his work included published accounts on the cultivation and diseases of fruit trees in the Maltese Islands, on orange culture, on vines, on scale insects, and on the pig. His book "Cacti. A Gardener's Handbook for their Identification and Cultivation" (London: Macmillan and Co., Ltd.) is well known and widely used.

The most valuable of Borg's works in-systematic botany, and one that will maintain his name among all interested in the flora of the Mediterranean region, is his "Descriptive Flora of the Maltese Islands including the Ferns and Flowering Plants" (Malta: Government Printing Office, 1927). This is a book of 846 pages written in English. It includes a lucid introduction to the history of botanical investigation of the islands, their geology, vegetation and flora. The bulk of the volume consists of carefully prepared descriptions of the families, genera and species of the vascular plants, including those naturalized or commonly cultivated, of Malta and the associated islands, together with their Maltese localities and Maltese and English names. The flore gives the impression not only of conscientious preparation but also of intimate personal acquaintance with the plants described. Malta is intensively cultivated over much of its surface and almost all the rest is heavily grazed (if grazed be the right word) by the almost omnivorous goats, and there is little natural vegetation left; but its flora is surprisingly rich and of considerable importance in studies of the phytogeographical problems of the Mediterranean Basin.

I met Borg only once, in his department in the University of Valetta, and recall him as a quiet, unassuming man devoted to his work but with the widest interest in all that related to his country. His widow, to whom his "Flora" is dedicated and who was his constant companion and assistant on botanical rambles, survives him. His large collection of cacti and other succulents has been left to the Argotti Botanic Gardens and he has made other bequests to his University.

W. B. TURRILL.

\section{Prof. E. Rádl}

Sove time in May 1942, Dr. Emanuel Rádl died in Prague at the age of sixty-nine. In early life he was a biologist of local distinction. His critical abilities first reached a wider public in 1909 when he published his "History of the Development of Biological Theories", in which he stressed the changes that had occurred with regard to the significance and the evidence for evolution during the nineteenth century. $\mathrm{He}$ was critical of certain Continental schools of biological thought and of various 'cell theories', of temporary 'fashions' in science and of Driesch's ideas on entelechy.

Later Rádl turned his attention to philosophy, changing his chair of biology for that of philosophy at the University of Prague. He wrote several works on the history and modern trends of philosophy, and in his "Present State of Philosophy and Psychology" (1933) he expressed the opinion that Anglo-Saxon countries were then "being infected with the bacilli of moral anarchy, spiritual decadence and cold 
intellectualism. . . Who knows how much of our confusion is due to the fact that England has ceased to be the spiritual backbone of Europe?"

For Rádl the real, the ultimate issue of our life and our civilization was the problem of whether there is an irresistible guarantee and vindication in our search for truth, whether there is an unshakable hinge on which all our ideas, definitions and standards revolve. Rádl was critical but not pessimistic; indeed, he disliked and attacked the pessimism of Oswald Sprengler and others. The philosophy of determinism and nihilism was "one of cowardly abdication and of miserable irresponsibility", but even in his own country Rádl met with considerable opposition. In 1935 he showed signs of physical fatigue, and it is clear that he foresaw the oncoming catastrophe. He never recovered and the circumstances of his last years hastened his end.

\section{G. Druce.}

WE regret to announce the following deaths :

Sir Peter Chalmers Mitchell, C.B.E., F.R.S., secretary of the Zoological Society of London during 1903-34, on July 2, aged eighty.

Mr. F. Oates, O.B.E., chief geologist in Tanganyika Territory, on June 10, aged fifty-six.

Dr. H. C. Redeke, the well-known Dutch authority on hydrobiology and fishery research, on April 10.

\section{NEWS and VIEWS}

\section{National Physical Laboratory for India}

The committee appointed by the governing body of the Council of Scientific and Industrial Research, India, in February 1943, to prepare a scheme for the establishment of a National Physical Laboratory for India has now issued a tentative report setting out the scope of the proposed laboratory and the staff, equipment and finances required to establish it. Such an institution is regarded as of fundamental importance both for the development of scientific research and for the promotion of organized industries in India, which possesses no metric, electrical, optical or other physical standards which can claim statutory acceptance or scientific precision. The National Physical Laboratory, Teddington, has served as the model for planning an Indian National Physical Laboratory, which as envisaged by the committee will consist of eight sections : weights and measures ; applied mechanics and materials; heat and power including low-temperature work; optics (including spectroscopy and photography); electricity (including magnetism, $\mathbf{X}$-rays and radioactivity); radio, sound and electro-acoustics; building and housing research ; and shipbuilding and navigational research. Separate institutions for aerodynamics and metallurgy are to be established in India, and accordingly such sections are not included in the proposed Laboratory.

Besides standardization work, the proposed Laboratory should undertake investigations relating to the survey, standardization and processing of primary resources and also fundamental research, and will provide facilities to university teachers for research during the vacations and also to research workers engaged in industry. It will serve as a vital link between the universities and industry. The proposed scheme contemplates the establishment of a Central Specifications Board modelled on the American Federal Specifications Board, which will undertake the formulation of specifications with the aid of the National Physical Laboratory in India and in consultation with consumers, producers and other interests. The report contemplates special grants for pilot plant and emphasizes the importance of having a fully equipped laboratory from the commencement. The emphasis is placed on equipment as much as on the permanent staff or its work, for the Committee considers that a central research station, partly or wholly supported by the State, should be in a position to help any industry requiring facilities for solving problems of immediate interest, besides serving as a repository of general knowledge and carrying out long-range research which will ultimately benefit the whole of industry.

\section{United Nations Relief and Rehabilitation Adminis- tration : European Agriculture}

THE importance of an early improvement in the food situation in Europe is stressed by the inclusion of an agricultural rehabilitation officer in every mission sent by the United Nations Relief and Rehabilitation Administration to the continent of Europe. Missions have been at work for some time in Greece and have more recently entered Jugoslavia and Czechoslovakia; another is preparing to leave for Poland. A special observer has been sent, at the request of the Dutch Government, to Holland. At the first council meeting of the Administration, the organization was charged with the duty of assisting governments in liberated areas in providing the supplies and service needed to enable farmers to sow and harvest essential crops, maintain dairy herds and rehabilitate farms. To this end the Administration may help in re-establishing experimental stations and essential agricultural institutions, organizations and services. The rehabilitation of fisheries is also within the scope of the Administration's activities. Its assistance has already been requested for the reequipment of veterinary laboratories in Czechoslovakia, Jugoslavia and Poland, and of the Marine Biological Institute in Greece. It is also pressing for immediate facilities to be granted to the International Office of Epizootics in Paris for the resumption of its valuable work in collecting and disseminating information on the occurrence and spread of epizootic disease, and in general on animal health and the means of preserving it. One of the duties of the agricultural officers of the Administration is to inquire into the state of agricultural, scientific and technical research in the country to which they are accredited, and to suggest where a study of results already obtained in the free world, or possibly the visit of a British or American specialist, might help in the solution of local problems.

\section{National Parks in the United States}

The National Park System of the United States appears to be in a healthy and progressive state. A review of its position in recent years is contained as one section in the Annual Report of the Secretary of the Interior for 1944 (Washington, D.C. : U.S. 